\title{
MATHEMATICAL REASONING ABILITIES OF STUDENTS IN TERMS OF FIELD DEPENDENCE (FD) COGNITIVE STYLE IN PROBLEM-SOLVING
}

\author{
Zaini ${ }^{1 *}$ \\ ${ }^{1}$ Sekolah Tinggi Teknologi Bontang \\ * Corresponding author E-mail: zaini.math@gmail.com
}

Keywords:

Cognitive Style;

Field Dependence; Mathematical Reasoning; Problem Solving; Polya

\begin{abstract}
Every individual has different abilities in translating problems because it is influenced by basic knowledge, experience, and cognitive. The cognitive types of FD were identical slower than others. This study describes the mathematical reasoning of students with cognitive type of FD in problem solving. The research data needed is the GEFT test, problem-solving tests, and interviews involving twostudents in level IV . All data were analyzed inductively. The results showed that students with the cognitive type of FD needed a long time to create connection to the problem thinking and they needed direction as a stimulus to stimulate their thinking. Lecturers can use realistic examples in the environment around them to make connections in their thinking
\end{abstract}

\section{Introduction}

NCTM mentions the ability to reason (mathematical reasoning) in learning mathematics as a mathematical ability that students must have. Meanwhile, Copi stated that reasoning is related to thinking activities to obtain conclusions/prove/solve problems by building new knowledge from true statements [1][2]. Therefore, reasoning skills are very important in learning mathematics besides other abilities. Other abilities are critical thinking, creative, working together, and communication [3].

Students who are faced with irregular problems can stimulate their thinking to be able to find solutions which in turn they have reasoning abilities Training students' reasoning skills to think critically, creatively, and smartly are given in international programs such as PISA studies (Program International Science Assessment) and TIMSS (Trends in Mathematics International and Science Study). These two international programs measure the level of knowledge, application and reasoning that have been followed by various countries, including Indonesia. The results of Indonesian students abilities are known to be at a low level, namely the achievement of points 386 397 in 2015 [4]. The scale and criteria for point acquisition include low (400), medium (475), high (550), and advanced (625) [5]. Details of the percentage of Indonesian students' ability in solving questions can be seen in Figure 1.

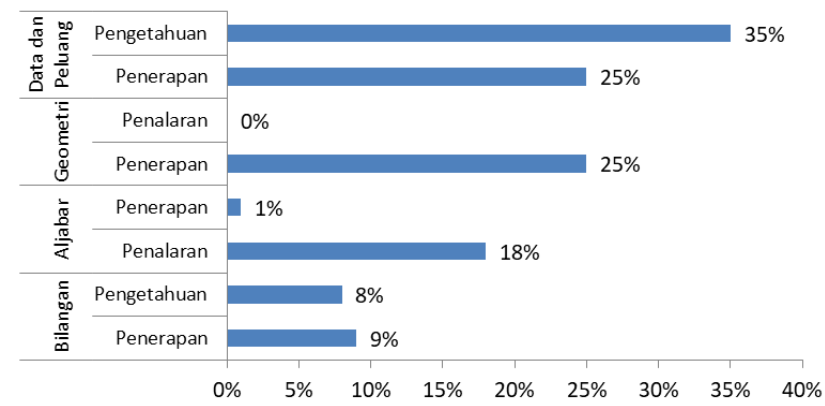

Fig. 1: Persentage of Correct Answer [5] 
From the results data (see Figure 1) it can be known that the maximum level of knowledge is $35 \%$, the level of application is only $25 \%$, and the level of reasoning is $18 \%$. From the three abilities, the student's reasoning ability was the lowest achievement compared with knowledge and application of concepts. This condition is justified because the thinking ability of Indonesian children is still underdeveloped [6].

The opportunity for students to think about collecting, compiling, and managing information as part of the process is not yet fully educational orientation. As a result, creativity to innovate, be creative, and all forms of self-development is distirbed and does not even occur. The final result is still a measure in providing evaluation without considering the process that has been carried out and takes a long time. Through the Ministry of Education and Culture Regulation 2019 has provided directions on the implementation of education and forms of student participation in learning. Learning as a process of change in behavior, attitudes and knowledge needs serious attention. Every good result comes from a good process and in turn will provide an increase in the quality of human resources which is the Indonesian government's program about independent learning.

Thinking to find a solution of a problem is an example of a learning activity that combines between physical activity and mental. Problems that can be used include routine questions - non-routine, opened (open ended), realistic, reasoning, forms of material implementation, and others. Problem solving can be said to be still part of the knowledge construction process. Through this process, students have experience and abilities that can be applied to their future. The form of problem solving in which there is a thinking process is not easy to make it happen. Several studies have found various errors such as concept errors, procedures, calculation errors, and others [7]. Other studies also said that students consist still need guidance from the teacher in order they can organize their thinking so that they can find solutions. Guidance can use Worksheets [8], Peers [9], and others. Vygotsky gave his view that the problems / assignments given to students are in their cognitive range or the closest developmental area (ZPD) [10].

Individual perspectives on each problem are definitely different because they are influenced by their level of knowledge, experience, and cognitive style [11] [12]. Likewise, the critical thinking process is influenced by cognitive style [13] and cognitive style has a relationship with problem-solving abilities [14]. Individual cognitive style types include Field Dependent (FD), Field Independent (FI), reflective and impulsive [11]. In the process of thinking, individuals with reflective and impulsive types are faster than FI and FD. Meanwhile, individuals with the FI style are more complex in solving problems than FD [15] and FD cannot separate information in its context [16]. This study will examine in depth the reasoning abilities of individuals with cognitive style of FD in problem solving.

\section{Method}

This research was carried out during pandemic of Covid-19 with online learning activities. During lecture activities, the lecturer has provided material handouts that can be used as a learning resource. This is in accordance with their role where lecturers in their learning activities function as facilitators [17][18]. During online learning activities, students are required to turn on the camera to maintain research originality. This research approach is descriptive qualitative research and aims to describe the process of mathematical reasoning of students in terms of cognitive style of FD in solving math problems. Identification of individual cognitive styles using the GEFT test with the provisions as shown in Table 1 and Table 2.

Table 1: Grouping individual cognitive styles [19]

\begin{tabular}{|c|c|}
\hline Score & Cognitive Style \\
\hline $\mathrm{T}<\mathrm{F}$ & FD \\
\hline $\mathrm{T}>\mathrm{F}$ & $\mathrm{FI}$ \\
\hline
\end{tabular}

Table 2: Grouping individual cognitive stylesbased on Test Point Score [20]

\begin{tabular}{|c|c|}
\hline Score Point & Cognitive Style \\
\hline $0-9$ & FD \\
\hline $10-13$ & FDI \\
\hline $14-18$ & FI \\
\hline
\end{tabular}

The subjects of this study were 2 students in level IV with a cognitive style of FD. They are students of the Informatics Engineering Study Program at the Bontang College of Technology. Students use the polya problem-solving method which consists of four steps, namely understanding the problem, devise plan, carry out the plan, and looking back. Collecting research data is the GEFT test, direct observation of problem solving accompanied by live interviews with the two students using the application. The overall results of the data are then analyzed inductively which includes data reduction, data exposure, and arranging conclusions.

\section{Results and Discussion}

\subsection{GEFT Test Results}

The GEFT test used consists of 3 parts, namely the First part has 7 questions, the Second and Third part each has 9 questions. Students' cognitive style is determined based on the answers in the second sessions and third sessions. If there are more correct answers than wrong answers, it includes having an FI style. Conversely, if there are fewer correct answers than wrong answers, it includes having a cognitive style of FD [19]. The quantity of correct answers is then converted based on a score of 0 - 18. The distribution of the score and the type of cognitive style includes a score 0 - 9 including FD, a score 10 - 13 including FDI (intermediate), and a score of 14 - 18 including FI [20].

In the GEFT test, the time provided is 15 minutes for 25 questions. The participants involved in the GEFT test were 31 people. From the results of the GEFT test, it is known that 19 students have an FD cognitive style, 9 students have an FDI cognitive style, and 3 students have a FI cognitive style. Of the 19 students with the cognitive style FD type, it is known that 4 students have a 0 score.From the group of students with the FD cognitive style type and through various other considerations such as being easy to communicate with and being able to express their open-mindedness, the research subject only involved 2 people who had the initials AB and AP. 


\subsection{Problem Solving and Mathematical Reasoning of Research Subjects}

The definition of absolute value is used as a strategy in finding solutions to the equation. This means that the problem that is solved by students is done by returning to its definition. An example of the absolute value solution using definition can be seen in Figure 2.

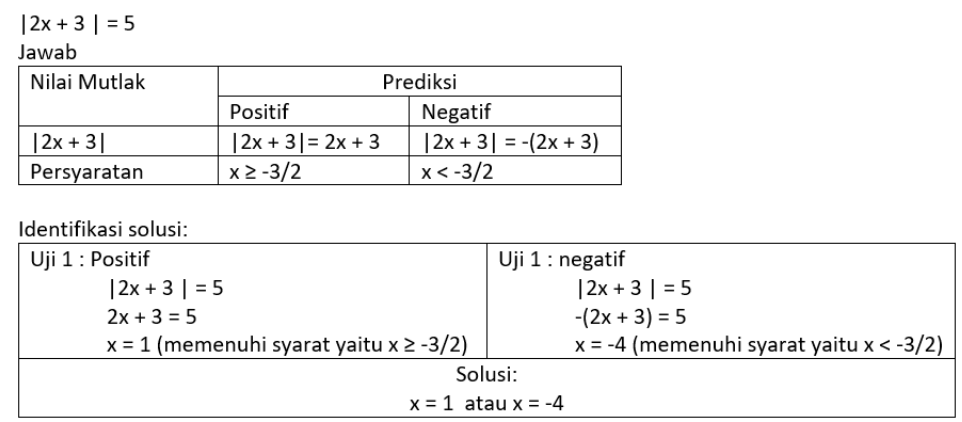

Fig. 2: Solution of Absolute Value Equation

Another strategy for solving absolute values is to use the property $|x|^{2}=x^{2}$ [21]. Meanwhile, in equations problems that have two absolute values, such as $|\mathrm{x}|+|\mathrm{x}-1|=2$ by using properties will cause the rank of the variable to be greater, which is more than 2 . Students' mathematical reasoning for the scope of absolute value material then becomes the subject of study in this study. In other studies it is known that student errors in solving absolute value include the use of inconsistent definitions, common mistakes such as changing the absolute value sign with regular brackets, and others [22].

The mathematical problem in this study is an absolute value that takes into account the identification of requirements in its definition. The problem in question can be observed in Figure 3.

1. $|3 \mathrm{x}+1|+|\mathrm{x}-2|=8$ !

2. $|2 x-1|+|x+2|=6-3 x$ !

Fig. 3: Absolute Value Problem

The problem description as in Figure 3 is the result of modification and development of the form of an equation which contains an absolute value is given by the lecturer. Giving problems to students is suggested to be within their cognitive range [10]. Problems that are close with the cognitive range are expected that they can solve them well and with it students have an overview of strategies and mastery so that their experiences are formed. The level of knowledge and experience are important because it influences to the perspective of each problem [11] [12]. Besides that, the lecturer also introduced stage of Polya's problem solving which consisted of four stages. To create this atmosphere, the lecturer has arranged handouts as a form of facilitating student learning. The handout arranged consists of a presentation of basic knowledge, examples and discussion, and practice questions.

Understanding the problem, , as the first step in solving Polya, AB and AP's efforts to understand the problem were done by reading and paying attention to what information was in the questions. They took a long time to explain what was understood. Through the confirmation made by the lecturer, in the end both of them were able to translate the information that was known, namely finding the value of $x$ that fulfilled the equation by involving more than one absolute value.

After both of them obtain the information needed on the problem, then identify the definition of each of the absolute values that exist in the problem. The identification results shown by both of them can be observed in Figure 4 .

$$
\begin{aligned}
& |3 x+1|= \begin{cases}3 x+1, x \geq-1 / 3 \\
-(3 x+1), x<-1 / 3\end{cases} \\
& |2 x-1|= \begin{cases}2 x-1, x \geq 1 / 2 \\
-(2 x-1), x<1 / 2\end{cases} \\
& \hline-(x+2), x<2
\end{aligned}
$$

Fig. 4: Absolute Value Problem

Based on the identification results as shown in Figure 4, both of them have had a good understanding of the definition of absolute value. They confirmed that the writing of that definition as modified result example of the handout discussion. Through this identification the second thinking activity was completed to understand the problem in the first stage of Polya.

Devise a plan, as the second stage of Polya, the lecturer invited the two students to think about various possible requirements on absolute value. The lecturer gave a thinking stimulus that "if one absolute value has two investigations to identify possible solutions, namely negative and positive, then how if there are two absolute values?". The stimulus is included by providing an example involving equations with one absolute value. From this stimulus, it appears that the two students still undergo confusion so that the connection between the thoughts of lecturers and students is not connected. In order for the expected connection to occur, the lecturer uses a realistic explanation that is around them, such as favorite food. With this explanation, finally, students find various possibilities for the two absolute values. These cases can be seen in Table 3 and Table 4.

Table 3: The Case of $x$ Value Requirement in Problem 1

\begin{tabular}{|c|c|c|c|c|}
\hline Absolute Value & Possibility 1 & Possibility 2 & Possibility 3 & Possibility 4 \\
\hline$|3 x+1|$ & Positive & Negative & Positive & Negative \\
\hline$|x-2|$ & Positive & Positive & Negative & Negative \\
\hline
\end{tabular}


Table 4: The Case of $x$ Value Requirement in Problem 2

\begin{tabular}{|c|c|c|c|c|}
\hline Absolute Value & Possibility 1 & Possibility 2 & Possibility 3 & Possibility 4 \\
\hline$|2 x-1|$ & Positive & Negative & Positive & Negative \\
\hline$|x+2|$ & Positive & Positive & Negative & Negative \\
\hline
\end{tabular}

From the identification of the existing possibilities, both of them still undergo confusion in translating the $x$ interval of each of the two possibilities which contains two statements. Therefore, the lecturer gave confirmation to present each statement in the form of a diagram. Through this confirmation, both of them can present the diagram correctly, but the connection of the two diagrams still needs to be given direction. The lecturer's direction with pressed that both of them should choose an area with a lot of lines traversed. In this direction, both of them can identify the $x$ interval as a requirement for $x$ which is the solution to the equation. The identification of the $x$ interval which is the requirement for completion can be seen in Tables 5 and 6.

Table 5: Requirements of $x$ Value in Problem 1

\begin{tabular}{|c|c|c|c|c|}
\hline Absolute Value & Possibility 1 & Possibility 2 & Possibility 3 & Possibility 4 \\
\hline$|3 x+1|$ & $3 x+1$ & $-(3 x+1)$ & $3 x+1$ & $-(3 x+1)$ \\
\hline$|x-2|$ & $x-2$ & $x-2$ & $-(x-2)$ & $-(x-2)$ \\
\hline$x$ value interval & $x \geq 2$ & $\varnothing$ & $-1 / 3 \leq x<2$ & $x<-1 / 3$ \\
\hline
\end{tabular}

Table 6: Requirements of $x$ Value in Problem 2

\begin{tabular}{|c|c|c|c|c|}
\hline Absolute Value & Possibility 1 & Possibility 2 & Possibility 3 & Possibility 4 \\
\hline$|2 x-1|$ & $2 x-1$ & $-(2 x-1)$ & $2 x-1$ & $-(2 x-1)$ \\
\hline$|x+2|$ & $x+2$ & $x+2$ & $-(x+2)$ & $-(x+2)$ \\
\hline$x$ value interval & $x \geq 1 / 2$ & $-2 \leq x<1 / 2$ & $\varnothing$ & $x<-2$ \\
\hline
\end{tabular}

Carry out the plan, at this stage students can continue to search for the $x$ value based on its probability. The $x$ interval in each case functions as an indicator of the $x$ value that will be the solution. In each case, the absolute value needs to be substituted for each problem to find the $x$ value that corresponds with the indicator. From the existing conditions, the thoughts of the two students were not connected to the thinking of the questions. The two students' thinking immediately concluded that the $x$ interval was the value of $x$ which fulfilled the equation. They assume that the problem has multiple $x$ values. In order students can find out their mistakes, the lecturer gives instructions to choose any $x$ value they expressed and substituted the $x$ value in the equation. Through this assignment, both of them finally realized their mistake.

The lecturer returned to gave directions to the two students to connect the possibilities they made with equations. The lecturer began with an example in order both of them have a problem thinking connection. From the examples given, both of them followed by rewriting the equation and identifying the $\mathrm{x}$ value that satisfied the probability that occurs as required. The identification carried out by both can be seen in Table 7 .

Table 7: Identification of $x$ Value in Problem 1

\begin{tabular}{|c|c|c|c|c|}
\hline Statements & $\begin{array}{c}\text { Equations } \\
|3 x+1|+|x-2|=8\end{array}$ & requirements & $\begin{array}{c}\text { Conformity of } \mathrm{x} \text { based } \\
\text { on requirements }\end{array}$ & Solutions \\
\hline Possibility 1 & $\begin{array}{c}(3 x+1)+(x-2)=8 \\
4 \mathrm{x}-1=8 \\
4 x=9 \\
x=\frac{9}{4}\end{array}$ & $x \geq 2$ & fulfill & \multirow{4}{*}{$\begin{array}{c}x=\frac{9}{4} \\
\quad \text { or } \\
x=-\frac{7}{4}\end{array}$} \\
\hline Possibility 2 & $\begin{array}{c}-(3 x+1)+(x-2)=8 \\
-2 x-3=8 \\
-2 x=11 \\
x=-\frac{11}{2}\end{array}$ & $\varnothing$ & There is no & \\
\hline Possibility 3 & $\begin{array}{c}(3 x+1)+(-(x-2))=8 \\
2 x+3=8 \\
2 x=5 \\
x=\frac{5}{2}\end{array}$ & $-1 / 3 \leq x<2$ & Not fulfill & \\
\hline Possibility 4 & $\begin{array}{c}-(3 x+1)+(-(x-2))=8 \\
-4 x+1=8 \\
-4 x=7 \\
x=-\frac{7}{4}\end{array}$ & $x<-1 / 3$ & Fulfill & \\
\hline
\end{tabular}

Table 8: Identification of the value of $x$ Identify the value of $x$ in problem 2

\begin{tabular}{|c|c|c|c|c|}
\hline Statements & $\begin{array}{c}\text { Equations } \\
|2 x-1|+|x+2|=6-3 \mathrm{x}\end{array}$ & Requirements & $\begin{array}{c}\text { Conformity of } \mathrm{x} \text { based } \\
\text { on requirement }\end{array}$ & Solutions \\
\hline Possibility 1 & $(2 x-1)+(x+2)=6-3 \mathrm{x}$ & $x \geq 1 / 2$ & Fulfill & \\
& $3 x+1=6-3 \mathrm{x}$ & & & \\
& $6 x=5$ & & & \\
\hline
\end{tabular}




\begin{tabular}{|c|c|c|c|c|}
\hline Possibility 2 & $\begin{array}{c}-(2 x-1)+(x+2)=6-3 \mathrm{x} \\
-x+3=6-3 \mathrm{x} \\
2 x=3 \\
x=\frac{3}{2}\end{array}$ & $-2 \leq x<1 / 2$ & Not fulfill & $x=\frac{5}{6}$ \\
\hline Possibility 3 & $\begin{array}{c}(2 x-1)+(-(x+2))=6-3 \mathrm{x} \\
x-3=6-3 \mathrm{x} \\
4 x=9 \\
x=\frac{9}{4}\end{array}$ & $\varnothing$ & There is no & \\
\hline Possibility 4 & $\begin{array}{c}-(2 x-1)+(-(x+2))=6-3 \mathrm{x} \\
-3 x-1=6-3 \mathrm{x} \\
-1=7\end{array}$ & $x<-2$ & Not fulfill & \\
\hline
\end{tabular}

Looking back as the final stage of solving Polya's problem. Both students were able to find an $\mathrm{x}$ value that fulfilled each of the problems but did not re-check. The lecturer returned to reminds the student of the initial findings that have been made in providing conclusions. From this information, the two students conducted an examination of the answers they obtained to be substituted for each equation. With confidence, they certify that the value is appropriate based on the results of recalculation.

\section{Conclusion}

Based on the results of data analysis, the researcher concluded and found that students with a cognitive style of FD could think well but it took a long time. They also need direction as a stimulus to stimulate their thinking connections to fit the thinking process of the problem. The initial thinking connection becomes a fundamental factor for the success of the thinking process at a later stage. To create a connection students' reasoning with cognitive style of FD is advised to use realistic examples around their environment.

\section{Acknowledgement}

This research was held in collaboration between researchers and the Research and Community Service Institutes (LPPM) STITEK Bontang through the LPPM DIPA contract in 2020. All funding for research implementation to publication in journals is sourced from LPPM. The researchers say gratitude to the Leader of the LPPM STITEK Bontang, Chair of the Informatics Engineering Study Program, students involved in research, and all those who have helped which cannot be mentioned one by one. Hopefully this research will contribute to educational research work in particular and mathematics education in general which examines about individual cognitive styles in problem solving.

\section{References}

[1] A. Hidayati and S. Widodo, "Proses Penalaran Matematis Siswa dalam Memecahkan Masalah Matematika pada Materi Pokok Dimensi Tiga Berdasarkan Kemampuan Siswa di SMA Negeri 5 Kediri,” J. Math Educ. Nusant., vol. Vol 1, no. 2, pp. 1-13, 2015.

[2] Suriassumantri, Filsafat Ilmu: Sebuah Pengantar Populer. Jakarta: Sinar Harapan, 2010.

[3] A. R. As'ari, "Potensi Pembelajaran Yang Menyenangkan Dalam Matematika," 2015.

[4] S. Mutmainah and U. Rosyidah, "Analisis Kemampuan Berpikir Matematis Tingkat Tinggi Ditinjau dari Kecerdasan Emosional," J. Teor. dan Apl. Mat., vol. 1, no. 1, pp. 70-74, 2017.

[5] S. Hadi and Novaliyosi, "TIMSS Indonesia (Trends in International Mathematics and Science Study)," Pros. Semin. Nas. Call Pap. Progr. Stud. Magister Pendidik. Mat. Univ. Siliwangi, pp. 562-569, 2019.

[6] T. Nusantara, "Peran Teknologi Informasi dan Komunikasi Dalam Reformasi Pembelajaran Berkarakter," 2010.

[7] W. H. Mailili, "Deskripsi hasil belajar matematika siswa gaya kognitif field independent dan field dependent," ANARGYA J. Ilm. Pendidik. Mat., vol. 1, no. 1, pp. 1-7, 2018.

[8] Zaini and F. Nur, "Penerapan Metode Penemuan Terbimbing Untuk Membantu Mahasiswa Off C 2010 Dalam Membuktikan Teorema Pada Geometri Euclid," J. Inspirasi Pendidik. Univ. Kanjuruhan Malang, vol. 3, no. 1, pp. 175-184, 2013.

[9] H. Hudojo, Pengembangan Kurikulum dan Pembelajaran Matematika. Malang: Kerjasama JIKA dengan FMIPA Universitas Negeri Malang, 2003.

[10] Zaini and Mufidah, "Kontruksi Pembuktian Teorema pada Matakuliah Geometri Euclid Melalui Aktivitas Think Pair Share Zaini," J. Inspirasi Pendidik. Univ. Kanjuruhan Malang, vol. 4, no. 1, pp. 1-16, 2014.

[11] H. A. Witkin, C. A. Moore, D. Goodenough, and P. W. Cox, "Field-Dependent and Field-Independent Cognitive Styles and Their Educational Implications," Rev. Educ. Res., vol. 47, no. 1, pp. 1-64, 1977, doi: 10.3102/00346543047001001.

[12] Sudarman, P. Setyosari, D. Kuswandi, and W. D. Dwiyogo, "The Effect of Learning Strategy and Cognitive Style toward Mathematical Problem Solving Learning Outcomes," IOSR J. Res. Method Educ., vol. 6, no. 3, pp. 137-143, 2016, doi: 10.9790/7388-060304137143.

[13] F. M. Singer, C. Voica, and I. Pelczer, "Cognitive styles in posing geometry problems: implications for assessment of mathematical creativity," ZDM - Math. Educ., vol. 49, no. 1, pp. 37-52, 2017, doi: 10.1007/s11858-016-0820-x.

[14] H. Ulya, "Hubungan Gaya Kognitif Dengan Kemampuan Pemecahan Masalah Matematika Siswa," J. Konselung GUSJIGANG, vol. 1, no. 2, 2015.

[15] R. E. Wulan, Eka Resti; Anggraini, "Gaya Kognitif Field-Dependent Dan Field-Independent Sebagai Jendela Profil Pemecahan Masalah Polya Dari Siswa SMP," Factor M, vol. 1, no. 2, pp. 123-142, 2019, doi: 10.30762/f_m.v1i2.1503.

[16] A. Dwi Susandi, C. Sa'Dijah, A. Rahman As'Ari, and Susiswo, "Students' critical ability of mathematics based on cognitive styles," J. Phys. Conf. Ser., vol. 1315, no. 1, 2019, doi: 10.1088/1742-6596/1315/1/012018.

[17] A. L. Felipe, T. C. Pham, and E. Amouroux, "Interdisciplinary Collaborative Teaching in Project-Based Learning Approach," in Integrated Engineering, 2017, pp. 1-8.

[18] Zaini, "Description of Students Thinking on Warshall-Floyd Algorithm," Int. J. Multi Discip. Sci., vol. 2, no. 2, pp. 57-65, 2019.

[19] U. Silma, I. Sujadi, and F. Nurhasanah, "Analysis of students' cognitive style in learning mathematics from three different frameworks," AIP Conf. Proc., vol. 2194, no. December, 2019, doi: 10.1063/1.5139850.

[20] N. Idris, Teaching and learning of mathematics : making sense and developing cognitive abilities. Kuala Lumpur, Malaysia: Utusan Publications \& Distributors, 2006.

[21] R. G. Bartle and D. R. Sherbert, Introduction to Real Analysis, Fourth Edi. USA: John Wiley \& Sons, 2011.

[22] T. A. Aziz, Supiat, and Y. Soenarto, "Pre-service secondary mathematics teachers' understanding of absolute value," Cakrawala Pendidik., vol. 38, no. 1, pp. 203-214, 2019, doi: 10.21831/cp.v38i1.21945. 